\title{
Performance of a shipwreck as an artificial fish habitat along Goa, west coast of India
}

\begin{tabular}{lll}
\hline Paper received: 08.01.2018 Revised received: 28.04.2018 & Re-revised received: $22.05 .2018 \quad$ Accepted: 02.06 .2018 \\
\hline
\end{tabular}

\section{Authors Info \\ G.B. Sreekanth", N.M. Lekshmi and A. Patil ${ }^{3}$ \\ ${ }^{1}$ ICAR-Central Coastal Agricultural Research Institute, Old Goa-403 402, India \\ ${ }^{2}$ ICAR-Central Institute of \\ Fisheries Technology, Cochin-682 029, India ${ }^{3}$ DIVE GOA, Goa-403 515, India \\ *Corresponding Author Email : gbsree@gmail.com}

\section{Edited by \\ Dr. Rajesh K.M.}

Reviewed by Dr. Md. Absar Alam Dr. R. B. Raizada

\section{Abstract}

Aim : The objective of the study was to test the hypothesis that submerged shipwrecks along the western coast of India can function as artificial fish habitats with trophic structure of fish assemblages similar to natural rocky reef habitats.

Methodology : The fish assemblages on shipwreck and natural reefs were analysed from September 2013 to December 2016 using diver assisted underwater visual census (UVC). Data collected on fish assemblages were used to compare the fish trophic structure between shipwreck and natural reefs using diversity indices, permutational multivariate analysis of variance and similarity percentage analysis.

Results : Fish abundance was two times greater on shipwreck than on natural reefs and the major trophic guilds on shipwreck were omnivores and carnivores. Multivariate analyses showed a distinct fish trophic structure on shipwreck from that of natural reefs and certain fish species differentiated the trophic structure of shipwreck from natural reefs. The high densities of Pomadasys furcatus, P. guoraca, Pempheris multiradiata, Lutjanus indicus, L. fulvus, Ostorhinchus compressus,, Epinephelus coioides, E. erythrurus, Monodactylus argenteus and Heniochus singularis contributed significantly to the average dissimilarity for fish assemblages in shipwreck from natural reefs. This has helped to differentiate the fish communities on shipwreck from natural reefs.

Interpretation: This study showed that shipwreck and natural reefs differ significantly in fish trophic structure. Fish species richness and abundance were significantly higher on shipwreck than natural

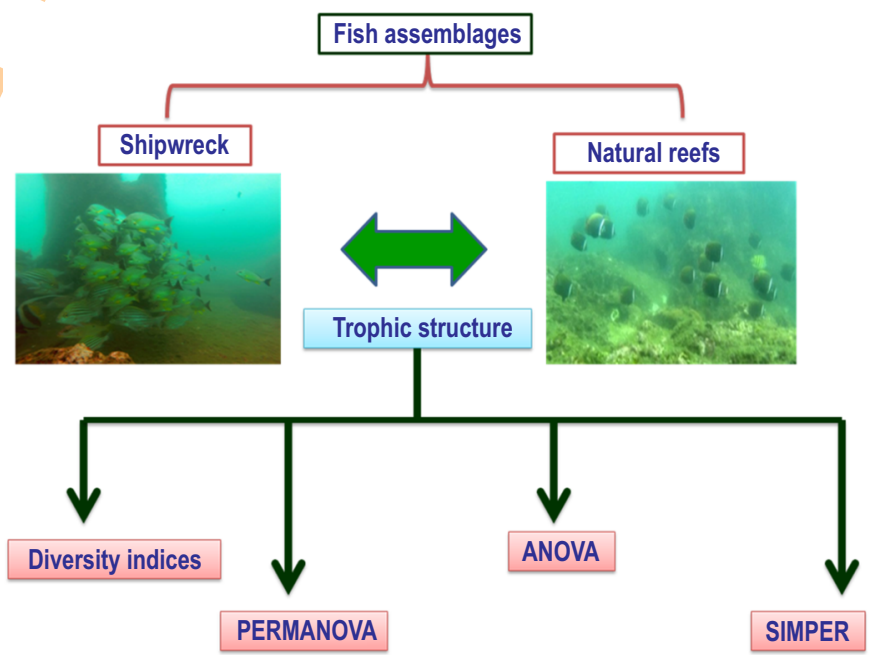
reefs. Therefore, the Greater species richness, abundance and diversity of fish communities on shipwreck could be a result of unique, complex and heterogeneous habitat features existing within the wreck.

Key words: Fish diversity, Grande Island, Habitat complexity, Natural reef, Shipwreck

How to cite: Sreekanth, G.B., N.M. Lekshmi and A. Patil: Performance of a shipwreck as an artificial fish habitat along Goa, west coast of India. J. Environ. Biol., 40, 170-176 (2019). 


\section{Introduction}

The global patterns in reef fisheries is alarming in the recent past on account of habitat degradation, coasta developmental activities, bleaching events, bio-erosion, wave actions, cyclonic storm surges and destructive fishing practices (Hughes et al., 2003). The decline in reef fisheries is primarily attributed to the alterations in its structural complexity and this is more apparent in tropical coastal ecosystems (Rogers et al., 2014). To compensate the degradation in reef habitats and decline in resources due to anthropogenic activities and natura disasters, Artificial Fish Habitats (AFHs) are deployed to emulate functions and habitat complexity of natural reefs such as protection, regeneration of habitats and aggregation and enhancement of fish populations (Bohnsack et al., 1994; Pitcher and Seaman, 2000; Adams et al., 2011). Therefore, these AFHs are compared with natural reef habitats in terms of diversity of fish species and trophic structure of fish assemblages (Arena et al., 2007; Consoli et al., 2015; Simon et al., 2013). The complexity of habitat, size, number of shelters and vertical relief are the major factors influencing the fish communities in AFHs (Bohnsack et al., 1994; Gratwicke and Speight, 2005; Simon et al., 2013). Therefore, many scientific reports compared the functiona trophic structure of fish assemblages between AFHs and natural reef habitats (Stone, 1985; Murray and Betz, 1994; Arena et al., 2007; Simon et al., 2013; Consoli et al., 2015). However, there are no reports from India which compared the trophic structure of fish assemblages between AFHs and natural reef habitats.

Fish assemblage studies on shipwrecks are quite challenging as they are found distant from the coast and their depth of submergence. The performance of shipwrecks as artificial fish habitats has been studied and these reports mostly describe the comparison of fish communities between shipwreck and natural reefs (Arena et al., 2007; Fowler and Booth, 2012; Simon et al., 2013; Consoli et al., 2015). These studies have also focused on ecological/functional comparison rather than the taxonomic studies. The shipwrecks in India have been investigated from the archaeological point of view (Gudigar et al., 1996; Gaur et al., 1997; Tripati and Gudigar, 2001; Tripati et al., 2010). However, the Indian shipwrecks are not thoroughly examined for their fish assemblages and species diversity. Therefore, in order to compare the fish assemblages on a shipwreck to the neighbouring natural reefs, a study was carried out employing underwater visual census (UVC) performed by divers in Grande Island, located in coastal waters of Goa, south west coast of India. In this study, trophic structure of fish assemblages was compared between an AFH (shipwreck) and two natural reef habitats to test the hypothesis that submerged shipwrecks can function as AFHs with trophic structure of fish assemblages similar to natural rocky reef habitats.

\section{Materials and Methods}

Study area : The islands around Goa on the western coast of India have extensive coastal and marine resources which are significant in both ecological and livelihood related contexts. The major coastal island ecosystems of Goa include Grande and Sao Jorge Islands near the mouth of Zuari estuary off Vasco De Gama in South Goa. The Grande Island encompasses coral reef habitats such as coral patches and submerged rocks with coral outcroppings Therefore, the reef habitats around the island are major tourist spots for the purpose of fishing, scuba diving, littering and recreational fishing. A $130 \mathrm{~m}$ metal cargo ship SS Rita reportedly arrived carrying a cargo of railroad tracks. The ship sank near Grande Island in 1950s and the wreck was salvaged leaving a superstructure covered with molluscs and small soft and hard corals. The superstructure of the shipwreck that had reached $10 \mathrm{~m}$ below the surface was selected as study site. To compare the fish community structure, two natural reef sites of similar depth profile (10-15 m) were selected quite far from the shipwreck at a distance of $1 \mathrm{~km}$. These natural reef sites are located at more than $500 \mathrm{~m}$ distance from each other.

Data collection: The fish assemblages on shipwreck and two natural reefs were studied from September 2013 to December 2016 by three trained divers, assisted underwater visual census (UVC). The divers used a non-destructive point count method to document the fish assemblage on the shipwreck and natural reef sites (Bohnsack and Bannerot, 1986). The fish communities on the shipwreck were counted using random transects, of 10 minutes each, conducted along the surfaces of the wreck covering an area of $1500 \mathrm{~m}^{2}$ at each run. Three replicates were carried out on the wreck and natural reef sites (total explored area $=13500 \mathrm{~m}^{2}$ ). During each sampling, a total of 8-12 transects were performed by the divers in shipwreck whereas a total 10-15 transects were carried out in natural reef sites. In natural reefs, transects were divided in such a way that the entire sampling area was covered within the sampling site. The counting was carried out at the bottom patches of natural reefs which match with the depth profile of shipwreck. A total of 80 UVCs were carried out on shipwreck and natural reefs during the study period.

Data analyses : Fishes were identified to family, generic and specific levels (Fischer and Bianchi, 1984). They were also classified into trophic guilds as planktivores, herbivores, piscivores, carnivores and omnivores (Elliot et al., 2007). The fish community was described by means of fish abundance $(\mathrm{N})$ and number of species (S). Further, two common specific diversity indices; Shannon Index and Margalef's Richness Index were also computed. To compare the abundance of fish assemblages on shipwreck and natural reefs, the abundance of each species, ' $X$ ' was transformed using $\log (X+1)$ transformation to reduce the effect of dominant species. Permutational multivariate analysis of variance (PERMANOVA) was applied using Bray-Curtis similarity matrix to test the differences in fish trophic structure between shipwreck and natural reefs (Anderson and Ter Braak, 2003). In addition, one-way permutational univariate analysis of variance (permutational ANOVA) was performed in order to detect the significant differences between abundance of each trophic guild between shipwreck and natural reefs. Using the species abundance data, the similarity in fish 
assemblages between shipwreck and natural reefs was compared employing similarity percentage (SIMPER) analysis. Applying this method, species that contribute significantly to fish assemblages were measured and ranked (Clarke, 1993). Thus, pair wise comparisons were made to identify the diagnostic species in shipwreck and natural reefs. All statistical analyses were carried out using PAST software.

\section{Results and Discussion}

A total of 55 species (Table 1) were counted on shipwreck and 36 on natural reefs. Thirty six species were found to be common for both shipwreck and natural reefs, while 19 species were exclusive to shipwreck. The most abundant species on the shipwreck were Pomadasys furcatus, $P$. guoraca, Pempheris multiradiata, Lutjanus indicus, L. fulvus, Ostorhinchus compressus Epinephelus coioides, E. erythrurus, Monodactylus argenteus and Heniochus singularis. On the other hand, Caesio cuning, C. caerulaurea, C. striata, C. xanthonota, Chaetodon collare, Acanthurus dussumieri, Arothron hispidus and Apolemichthys xanthurus were the dominant species at natural reefs (Table 1). Total fish abundance was almost two times greater on shipwreck (1187.1) compared to natural reefs (603.2, 549.7) (Table 2). The major trophic guilds on shipwreck were omnivores and carnivores with both the guilds being frequent in UVC (Table 3). In contrast, omnivores and planktivores were the dominant tropic guilds in natural reef habitats (Table 3). Shannon and Margalef's indices were significantly higher for shipwreck habitat in comparison with natural reefs (Table 2). However, mean abundance, species richness and diversity were not significantly different between natural reef patches (Table 2).

PERMANOVA showed a distinct fish trophic structure on shipwreck from that of natural reefs (Table 4). ANOVA results showed that on the basis of habitat type, the mean density of carnivores, omnivores, planktivores and herbivores varied significantly between shipwreck and natural reefs. However, no significant difference was observed for various trophic guilds between the two natural reef sites. In SIMPER, certain fish species which differentiated the trophic structure of shipwreck and natural reefs were identified (Table 5), and there were 55.1\% and $56.9 \%$ average dissimilarities for fish assemblages in

Table 1 : Classification and Mean abundance, Standard Errors (SE) and Frequency of Occurrence (Oc) of fish species recorded from shipwreck and natural reefs, Column "Guild" indicates trophic guilds (HR-herbivores, CR-carnivore, OM-omnivore, PK-planktivore, PS-piscivore)

\begin{tabular}{|c|c|c|c|c|c|c|c|c|}
\hline \multirow[t]{2}{*}{ Family } & \multirow[t]{2}{*}{ Species } & \multirow[t]{2}{*}{ Guild } & \multicolumn{2}{|c|}{ Shipwreck } & \multicolumn{2}{|c|}{ Natural reef 1} & \multicolumn{2}{|c|}{ Natural reef 2} \\
\hline & & & Mean \pm SE & Oc & Mean \pm SE & Oc & Mean $\pm S E$ & Oc \\
\hline Acanthuridae & Acanthurus blochii & $\mathrm{HR}$ & $0.44 \pm 0.02^{\mathrm{a}}$ & 64 & $0.39 \pm 0.10^{b}$ & 78 & $0.36 \pm 0.10^{b}$ & 74 \\
\hline Acanthuridae & Acanthurus dussumieri & $\mathrm{HR}$ & $1.26 \pm 0.04^{\mathrm{a}}$ & 91 & $1.21 \pm 0.09^{\mathrm{a}}$ & 92 & $1.18 \pm 0.03^{\mathrm{a}}$ & 94 \\
\hline Antennariidae & Antennarius commersonii & $\mathrm{CR}$ & $0.07 \pm 0.08^{\mathrm{a}}$ & 22 & $0.05 \pm 0.04^{b}$ & 18 & $0.09 \pm 0.06^{b}$ & 22 \\
\hline Apogonidae & Ostorhinchus compressus & $\mathrm{OM}$ & $2.17 \pm 0.03$ & 100 & & & & \\
\hline Balistidae & Odonus niger & PK & $0.26 \pm 0.01^{\mathrm{b}}$ & 43 & $0.77 \pm 0.12^{\mathrm{a}}$ & 85 & $0.71 \pm 0.15^{\mathrm{a}}$ & 88 \\
\hline Blennidae & Blenniella chrysospilos & $\mathrm{OM}$ & $1.19 \pm 0.04^{\mathrm{a}}$ & 83 & $0.31 \pm 0.12^{b}$ & 63 & $0.43 \pm 0.12^{b}$ & 69 \\
\hline Caesionidae & Caesio caerulaurea & PK & $0.74 \pm 0.05^{\mathrm{b}}$ & 35 & $1.54 \pm 0.03^{\mathrm{a}}$ & 100 & $1.56 \pm 0.03^{\mathrm{a}}$ & 96 \\
\hline Caesionidae & Caesio cuning & PK & $1.16 \pm 0.03^{b}$ & 74 & $1.60 \pm 0.02^{\mathrm{a}}$ & 88 & $1.57 \pm 0.04^{\mathrm{a}}$ & 82 \\
\hline Caesionidae & Caesio striata & PK & $1.39 \pm 0.02^{\mathrm{a}}$ & 54 & $1.53 \pm 0.02^{\mathrm{a}}$ & 82 & $1.49 \pm 0.03^{a}$ & 80 \\
\hline Caesionidae & Caesio xanthonota & PK & $1.36 \pm 0.03^{\mathrm{a}}$ & 82 & $1.45 \pm 0.02^{\mathrm{a}}$ & 83 & $1.43 \pm 0.04^{\mathrm{a}}$ & 81 \\
\hline Carangidae & Caranx sp. & CR & $0.85 \pm 0.03^{\mathrm{a}}$ & 83 & $0.83 \pm 0.04^{\mathrm{a}}$ & 68 & $0.76 \pm 0.03^{\mathrm{a}}$ & 63 \\
\hline Carangidae & Gnathanodon speciosus & $\mathrm{CR}$ & $1.45 \pm 0.02$ & 98 & & & & \\
\hline Carangidae & Trachinotus baillonii & $\mathrm{CR}$ & $1.02 \pm 0.10^{\mathrm{a}}$ & 89 & $0.04 \pm 0.04^{b}$ & 37 & $0.06 \pm 0.03^{b}$ & 29 \\
\hline Chaetodontidae & Heniochus acuminatus & OM & $1.81 \pm 0.01$ & 100 & & & & \\
\hline Chaetodontidae & Heniochus singularis & $\mathrm{OM}$ & $1.48 \pm 0.02$ & 100 & & & & \\
\hline Chaetodontidae & Heniochus intermedius & $\mathrm{OM}$ & $1.16 \pm 0.11$ & 100 & & & & \\
\hline Chaetodontidae & Chaetodon collare & $\mathrm{OM}$ & $1.47 \pm 0.03^{\mathrm{a}}$ & 91 & $1.51 \pm 0.03^{\mathrm{a}}$ & 72 & $1.50 \pm 0.03^{\mathrm{a}}$ & 73 \\
\hline Chaetodontidae & Chaetodon decussatus & OM & $1.31 \pm 0.04$ & 100 & & & & \\
\hline Diodontidae & Diodon liturosus & $\mathrm{OM}$ & $1.15 \pm 0.03$ & 91 & & & & \\
\hline Ephippidae & Platax orbicularis & OM & $0.67 \pm 0.08$ & 77 & & & & \\
\hline Haemulidae & Plectorhinchus chubbi & $\mathrm{OM}$ & $1.42 \pm 0.10^{\mathrm{a}}$ & 100 & $0.05 \pm 0.05^{\mathrm{b}}$ & 23 & $0.22 \pm 0.12^{b}$ & 27 \\
\hline Haemulidae & Pomadasys furcatus & $\mathrm{CR}$ & $1.74 \pm 0.04$ & 100 & & & & \\
\hline Haemulidae & Pomadasys guoraca & $\mathrm{CR}$ & $1.18 \pm 0.04$ & 100 & & & & \\
\hline Haemulidae & Plectorhinchus gibbosus & $\mathrm{CR}$ & $1.29 \pm 0.05^{\mathrm{a}}$ & 100 & $0.46 \pm 0.11^{\mathrm{b}}$ & 36 & $0.56 \pm 0.08^{\mathrm{b}}$ & 36 \\
\hline Lutjanidae & Lutjanus indicus & $\mathrm{CR}$ & $1.84 \pm 0.02$ & 100 & & & & \\
\hline Lutjanidae & Lutjanus russelli & $\mathrm{CR}$ & $1.28 \pm 0.04$ & 100 & & & & \\
\hline Lutjanidae & Lutjanus argentimaculatus & $\mathrm{CR}$ & $1.23 \pm 0.04^{\mathrm{a}}$ & 97 & $0.50 \pm 0.10^{b}$ & 28 & $0.38 \pm 0.08^{b}$ & 24 \\
\hline
\end{tabular}




\begin{tabular}{|c|c|c|c|c|c|c|c|c|}
\hline Lutjanidae & Lutjanus fulvus & $\mathrm{CR}$ & $1.77 \pm 0.04$ & 98 & & & & \\
\hline Lutjanidae & Lutjanus rivulatus & $\mathrm{CR}$ & $1.19 \pm 0.04^{\mathrm{a}}$ & 92 & $0.13 \pm 0.07^{b}$ & 32 & $0.11 \pm 0.06^{b}$ & 43 \\
\hline Lutjanidae & Pinjalo pinjalo & $\mathrm{OM}$ & $1.40 \pm 0.02^{\mathrm{a}}$ & 94 & $0.62 \pm 0.11^{b}$ & 56 & $0.43 \pm 0.11^{b}$ & 44 \\
\hline Monocanthidae & Aluterus scriptus & $\mathrm{OM}$ & $0.66 \pm 0.08$ & 83 & & & & \\
\hline Monodactylidae & Monodactylus argenteus & $\mathrm{OM}$ & $1.50 \pm 0.02$ & 85 & & & & \\
\hline Muraenidae & Gymnothorax flavimarginatus & CR & $0.20 \pm 0.01^{\mathrm{b}}$ & 46 & $0.81 \pm 0.07^{\mathrm{a}}$ & 74 & $0.80 \pm 0.09^{\mathrm{a}}$ & 68 \\
\hline Muraenidae & Gymnothorax javanicus & $\mathrm{CR}$ & $0.21 \pm 0.03^{b}$ & 44 & $0.72 \pm 0.08^{a}$ & 77 & $0.68 \pm 0.09^{a}$ & 70 \\
\hline Nemipteridae & Scolopsis vosmeri & $\mathrm{CR}$ & $1.42 \pm 0.02$ & 93 & & & & \\
\hline Pempheridae & Pempheris multiradiata & $\mathrm{OM}$ & $2.17 \pm 0.02$ & 100 & & & & \\
\hline Pomacanthidae & Apolemichthys xanthurus & $\mathrm{OM}$ & $1.30 \pm 0.03^{\mathrm{a}}$ & 100 & $0.99 \pm 0.05^{b}$ & 64 & $0.95 \pm 0.07^{b}$ & 62 \\
\hline Pomacanthidae & Pomacanthus annularis & $\mathrm{OM}$ & $0.34 \pm 0.04^{b}$ & 63 & $0.78 \pm 0.05^{\mathrm{a}}$ & 82 & $0.69 \pm 0.06^{a}$ & 84 \\
\hline Pomacentridae & Abudefduf bengalensis & $\mathrm{OM}$ & $1.49 \pm 0.13^{\mathrm{a}}$ & 100 & $0.74 \pm 0.13^{b}$ & 57 & $0.75 \pm 0.12^{b}$ & 52 \\
\hline Pomacentridae & Amblyglyphidodon aureus & PK & $0.35 \pm 0.02^{b}$ & 52 & $0.83 \pm 0.11^{\mathrm{a}}$ & 73 & $0.74 \pm 0.13^{\mathrm{a}}$ & 72 \\
\hline Pomacentridae & Chrysiptera hemicyanea & $\mathrm{OM}$ & $0.79 \pm 0.04^{\mathrm{a}}$ & 47 & $0.71 \pm 0.09^{a}$ & 79 & $0.69 \pm 0.10^{a}$ & 76 \\
\hline Pomacentridae & Chrysiptera parasema & $\mathrm{OM}$ & $0.24 \pm 0.04^{\mathrm{a}}$ & 42 & $0.16 \pm 0.07^{\mathrm{a}}$ & 75 & $0.19 \pm 0.08^{\mathrm{a}}$ & 80 \\
\hline Pomacentridae & Chrysiptera sp. & $\mathrm{OM}$ & $0.63 \pm 0.05^{\mathrm{a}}$ & 67 & $0.58 \pm 0.09^{a}$ & 84 & $0.57 \pm 0.09^{\mathrm{a}}$ & 82 \\
\hline Scorpaenidae & Pterois volitans & $\mathrm{CR}$ & $0.54 \pm 0.05^{\mathrm{a}}$ & 100 & $0.48 \pm 0.07^{\mathrm{a}}$ & 82 & $0.42 \pm 0.08^{\mathrm{a}}$ & 88 \\
\hline Scorpaenidae & Scorpaenopsis barbata & CR & $0.70 \pm 0.04$ & 74 & & & & \\
\hline Serranidae & Cephalopholis formosa & $\mathrm{CR}$ & $1.24 \pm 0.03^{\mathrm{a}}$ & 91 & $0.70 \pm 0.07^{b}$ & 42 & $0.68 \pm 0.08^{b}$ & 44 \\
\hline Serranidae & Epinephelus coioides & $\mathrm{CR}$ & $1.75 \pm 0.02^{\mathrm{a}}$ & 100 & $0.07 \pm 0.05^{b}$ & 53 & $0.04 \pm 0.04^{b}$ & 48 \\
\hline Serranidae & Epinephelus erythrurus & $\mathrm{CR}$ & $1.51 \pm 0.02^{\mathrm{a}}$ & 96 & $0.70 \pm 0.09^{b}$ & 31 & $0.54 \pm 0.09^{b}$ & 38 \\
\hline Serranidae & Epinephelus diacanthus & $\mathrm{CR}$ & $0.71 \pm 0.05^{\mathrm{a}}$ & 92 & $0.12 \pm 0.04^{b}$ & 29 & $0.17 \pm 0.07^{b}$ & 34 \\
\hline Siganidae & Siganus canaliculatus & $\mathrm{HR}$ & $1.31 \pm 0.02^{\mathrm{a}}$ & 92 & $0.52 \pm 0.10^{b}$ & 43 & $0.51 \pm 0.11^{b}$ & 54 \\
\hline Siganidae & Siganus javus & $\mathrm{HR}$ & $0.91 \pm 0.06$ & 85 & & & & \\
\hline Sphyraenidae & Sphyraena jello & PS & $0.82 \pm 0.07^{\mathrm{a}}$ & 64 & $0.79 \pm 0.08^{a}$ & 53 & $0.69 \pm 0.08^{\mathrm{a}}$ & 62 \\
\hline Tetraodontidae & Arothron hispidus & $\mathrm{OM}$ & $1.36 \pm 0.03^{\mathrm{a}}$ & 96 & $1.09 \pm 0.10^{b}$ & 51 & $0.97 \pm 0.11^{b}$ & 61 \\
\hline Tetraodontidae & Arothron immaculatus & $\mathrm{OM}$ & $1.04 \pm 0.04^{\mathrm{a}}$ & 74 & $0.50 \pm 0.11^{\mathrm{b}}$ & 32 & $0.57 \pm 0.11^{\mathrm{b}}$ & 35 \\
\hline Zanclidae & Zanclus cornutus & $\mathrm{OM}$ & $1.27 \pm 0.03^{\mathrm{a}}$ & 82 & $0.11 \pm 0.06^{b}$ & 42 & $0.15 \pm 0.07^{b}$ & 36 \\
\hline
\end{tabular}

The superscript for the mean values indicates the grouping obtained in the post-hoc comparison and the same superscript shows no significant difference for the variables between shipwreck and control sites. Grouping was carried out only for species observed from all the three sites (shipwreck and natural reefs)

shipwreck from the two natural reef sites. High densities of Pomadasys furcatus, P. guoraca, Pempheris multiradiata, Lutjanus indicus, L. fulvus, Ostorhinchus compressus Epinephelus coioides, E. erythrurus, Monodactylus argenteus and Heniochus singularis contributed significantly to the average dissimilarity for fish assemblages on shipwreck from natural reefs (Table 5). The count of fish species (55) recorded on the shipwreck, in this study, was considerably high as compared with previous reports from sunken vessels of South-east Florida (Arena et al., 2007), South-eastern Brazil (Simon et al., 2013), Central Mediterranean Sea (Consoli et al., 2015) and Southern Tyrrhenian Sea (Sinopoli et al., 2015).

The high count of fish species, in this study, could be a result of the diver assisted UVC in which demersal and cryptobenthic species were recorded by trained divers exploring the crevices, holes and shelter habitats in the wreck. The exclusive species on shipwreck included Heniochus acuminatus, $H$. singularis, $\mathrm{H}$. intermedius, Chaetodon decussatus, Pempheris multiradiata, Ostorhinchus compressus, Siganus javus, Lutjanus indicus, L. russelli, L. fulvus, Pomadasys furcatus, P. guoraca, Monodactylus argenteus and Platax orbicularis. All these species are generally deep water bottom dwelling reef fishes residing on hard substrates. Thus, it is clearly understood that the shipwreck has definitely served as an excellent habitat for these diverse fish species covering all the trophic levels. The haemulids species such as $P$. furcatus and $P$. guoraca accounted for greatest difference in trophic structure of fish assemblages for shipwreck from natural reefs. The greater abundance of haemulid species distinguished the fish trophic structure between shipwreck and natural reefs in many scientific reports (Simon et al., 2013; Consoli et al., 2015). These species are carnivorous foraging on mobile invertebrates including bryozoans, hydrozoans and sponges. During day time, these species are reported to exist at deeper areas with hard bottom and at night, they migrate to soft foraging sites to feed on in-faunal invertebrates (Simon et al., 2013). It is reported that this diurnal preference in habitat characteristics for these species are available in shipwreck and therefore, their biomass was significantly higher on shipwreck (Simon et al., 2013). Moreover, haemulids prefer shelf edge habitats and edges of rocks to minimize the energy for searching and resting (Manooch and Barans, 1982; Froese and Pauly, 2015). The shipwrecks are reported to provide shelter, foraging areas and resting sites for haemulids at the cost of less energy (Arena et al., 2007), and this might be the reason for their greater abundance on the shipwreck noticed in this study. 
Table 2 : Mean and Standard Error (SE) values of species abundance, Margalef's Richness Index and Shannon Index for fish assemblages in shipwreck and natural reef sites

\begin{tabular}{llll}
\hline Site & Abundance & Margalef & Shannon \\
\cline { 2 - 4 } & Mean \pm SE & Mean \pm SE & Mean \pm SE \\
\hline Natural reef1 & $603.2 \pm 14.4^{\mathrm{b}}$ & $7.59 \pm 0.16^{\mathrm{b}}$ & $3.14 \pm 0.03^{\mathrm{b}}$ \\
Natural reef2 & $549.7 \pm 20.5^{\mathrm{b}}$ & $7.52 \pm 0.19^{\mathrm{b}}$ & $3.10 \pm 0.04^{\mathrm{b}}$ \\
Shipwreck & $1187.1 \pm 21.5^{\mathrm{a}}$ & $12.25 \pm 0.04^{\mathrm{a}}$ & $3.91 \pm 0.03^{\mathrm{a}}$ \\
\hline
\end{tabular}

Superscript for the mean values indicate grouping obtained in the post-hoc comparison and same superscript shows no significant difference for the variables between shipwreck and control sites

Table 3 : Comparison of percentage contribution and mean abundance of various fish trophic guilds (carnivores, herbivores, omnivores, planktivores and piscivores) between shipwreck and natural reef sites

\begin{tabular}{lll}
\hline Groups & Shipwreck & Natural reef \\
\hline Carnivore (\%) & $37.9\left(23.19 \pm 0.53^{\mathrm{a}}\right)$ & $22.7\left(10.9 \pm 0.59^{b}\right)$ \\
Herbivore (\%) & $6.4\left(3.92 \pm 0.40^{\mathrm{a}}\right)$ & $8.7\left(4.17 \pm 0.88^{\mathrm{a}}\right)$ \\
Omnivores (\%) & $45.8\left(28.02 \pm 0.49^{\mathrm{a}}\right)$ & $33.8\left(16.26 \pm 0.79^{\mathrm{b}}\right)$ \\
Planktivores (\%) & $8.6\left(5.26 \pm 0.82^{b}\right)$ & $31.7\left(15.22 \pm 0.79^{\mathrm{a}}\right)$ \\
Piscivores (\%) & $1.3(0.82)$ & $3.1(1.48)$ \\
\hline
\end{tabular}

Value in parentheses represent mean monthly abundance with standard error. Superscript for the mean values indicate grouping obtained in the posthoc comparison and the same superscript shows no significant difference for the variables between shipwreck and control sites

The planktivorous species dominated natural reef sites in this study is surprisingly contrast to the earlier reports on fish trophic structure from shipwreck and natural reefs (Rilov and Benayahu, 2000; Simon et al., 2013). These species prefer waters with high plankton availability and the abundance of plankton is influenced by primary productivity, incidence of solar radiation, wave action and current strength (Clarke et al., 2009). The shallow natural reef sites near the surface have reduced planktivore biomass on account of resistance to water movements, reduced currents and plankton movement. On the other hand, shipwrecks have upper water column free of obstacles as the bottom of the wreck reaches to more deeper zones (Arena et al., 2007; Simon et al., 2013; Rilov and Benayahu, 2000). However, though these factors affect the plankton distribution in the habitat, the major factor determining the plankton availability could be primary productivity and incidence of solar radiation. It should also be noted that the incidence of solar radiation and primary productivity will be significantly higher in a patchy reef compared to complex physical habitat such as shipwreck. Therefore, the plankton biomass would be more in natural reefs than shipwreck which ultimately attracts the planktivorous fishes it for grazing.

If the complexity of habitat is increasing, there will be an increase in the diversity and abundance of species due to availability of refuges (Bohnsack et al., 1994). Due to increase in the number of refuges, the small species will be under less predation risk and hence their availability get enhanced. The shipwrecks possess complexity and heterogeneity as a habitat for fish assemblages which appears to be the important factors to explain its unique and diverse fish communities (Lassau and Hochuli, 2004; Consoli et al., 2015). Fishes prefer a robust and

Table 4 : One way permutational multivariate analysis of variance (PERMANOVA) analyzing the effect of factor wreck, on fish assemblages based on Bray-Curtis dissimilarities of log transformed data

\begin{tabular}{llllll}
\hline Source & df & SS & MSS & F & P (perm) \\
\hline Site & 2 & 0.67 & 0.335 & 66.34 & $<0.001$ \\
Res & 37 & 2.49 & 0.067 & & \\
Total & 39 & & & & \\
\hline Pair wise tests & & & & 144.1 & $<$ (perm) \\
\hline Shipwreck*NR1 & & & 114.5 & $<0.001^{* *}$ \\
Shipwreck*NR2 & & & 0.93 & $<0.001^{* *}$ \\
NR1*NR2 & & & $0.51^{\text {Ns }}$ \\
\hline
\end{tabular}

NR- natural reef; ** significant at $1 \%$ level; NS not significant 
Table 5 : Diagnostic species, determined using SIMPER, contributing to difference in fish assemblage of shipwreck from natural reefs

\begin{tabular}{lll}
\hline Species & Dissimilarity (\%) & $\begin{array}{l}\text { Cumulative } \\
\text { dissimilarity (\%) }\end{array}$ \\
\hline Pempheris multiradiata & 4.41 & 4.41 \\
Pomadasys furcatus & 4.41 & 8.82 \\
Pomadasys guoraca & 3.73 & 12.55 \\
Lutjanus indicus & 3.67 & 16.22 \\
Lutjanus fulvus & 3.60 & 19.82 \\
Ostorhinchus compressus & 3.53 & 23.35 \\
Epinephelus coioides & 3.39 & 26.74 \\
Monodactylus argenteus & 3.05 & 29.79 \\
Heniochus singularis & 3.01 & 32.80 \\
\hline
\end{tabular}

Species contributed to more than $3 \%$ of average dissimilarity is presented in the table

big physical structure for shelter in which there are lot of hideouts for them to safeguard from predators and to ambush at their prey as well. The presence of pipes, articulated structures, cabins, crevices, holes, hull fracture, crossbars and bulkheads makes the shipwreck a complex habitat for fish populations (Sinopoli et al., 2015). These diverse sheltering habitats on shipwreck makes it superior in fish density compared to patchy natural reefs. Further the two most abundant species on the wreck, P. multiradiata and 0 . compressus were omnivores. This confirms that the shipwreck provides both planktivorous and carnivorous food sources for these species. The previous scientific reports on the fish assemblages states that the planktivores are the major feeding group on shipwrecks (Arena et al., 2007). However, benthic carnivores and omnivores represented the most abundant groups on shipwreck followed by herbivores and planktivores in this study. Therefore, it is obvious that the shipwrecks function as complex fish habitats with foraging sites and feeding resources for all these groups.

The complexity of natural reefs of Grande Island is comparatively less than other major reef systems along the west coast of India (Venkataraman, 2003). There is a serious concern on the health of natural reefs as fish habitat in the coastal regions of India including the Grande Island in Goa. Excessive sedimentation, increased temperature, reduced salinity, climate change and ocean acidification cause damage to natural reefs (Manikandan et al., 2016). A reduction in salinity near Grande Island is the end result of surplus runoff during south-west monsoon, and this will cause reduction in the extent of reef habitats and species diversity (Manikandan et al., 2016). Intense tourism activities associated with the natural reef habitats resulted in physical damage of the habitats and prevalence of coral diseases (Lamb et al., 2014). Therefore, the fish assemblages could have moved to a better complex habitat in the vicinity i.e., shipwreck. Shipwrecks are bestowed with high vertical relief in the water column which may increase the settlement of juvenile fish populations and attract the larval fishes (Arena et al., 2007). The present study has indicated that the shipwrecks can act as artificial fish habitat, attracting fish assemblages contributing to a greater species diversity.

\section{Acknowledgments}

The author acknowledges the guidance, support and encouragement from the Director, ICAR-CCARI, Dr. E. B. Chakurkar and former Director, Dr. Narendra Pratap Singh. The support and contributions from former Director of Fisheries, Dr. Shamila Monteiro and Superintendent of Fisheries, Dr. Hrishikesh Pawar are greatly appreciated.

\section{References}

Adams, C., B. Lindberg and J. Stevely: The economic benefits associated with Florida's artificial reefs. ADIS Document No. FE 649. Food and Resource Economics Department, Florida Cooperative Extension Service, Institute of Food and Agricultural Sciences, University of Florida, Gainesville, FL (2011).

Anderson, M.J. and C.J.F. Ter Braak: Permutation tests for multifactorial analysis of variance. J. Stat. Comput. Sim., 73, 85-113 (2003).

Arena, P.T., L.K.B. Jordan and R.E. Spieler: Fish assemblages on sunken vessels and natural reefs in South-east Florida, USA. Hydrobiol., 580, 157-171 (2007).

Bohnsack, J.A. and S.P. Bannerot: A stationary visual census technique for quantitatively assessing community structure of coral reef fishes. U.S. Dept. Of Commerce NOAA Technical Report, 41, 1-15 (1986).

Bohnsack, J.A., D.E. Harper, D.B. McClellan and M. Hulsbeck: Effects of reef size on colonization and assemblage structure of fishes at artificial reefs off eastern Florida, USA. Bull. Mar. Sci., 55, 796823(1994)

Clarke, K.R.: Non-parametric multivariate analyses of changes in community structure. Australian J. Ecol., 18, 117-143(1993).

Clarke, R.D., C.M. Finelli and E.J. Buskey: Water flow controls distribution and feeding behavior of two co-occurring coral reef fishes: II. Laboratory experiments. Coral Reefs, 28, 475-488 (2009).

Consoli, P., A. Martino, T. Romeo, M. Sinopoli, P. Perzia, S. Canese, P. Vivona and F. Andalaro: The effect of shipwrecks on associated fish assemblages in the Central Mediterranean Sea. J. Mar. Biol. Assoc. UK, 95, 17-24 (2015).

Elliot, M., A.K. Whitfield, I.C. Potter, S.J.M. Blaber, D.P. Cyrus, F.G. Nordlie and T.D. Harrison: The guild approach to categorizing estuarine fish assemblages: A global review. Fish Fish., 8, 241-268 (2007).

Fischer, W. and G. Bianchi: FAO Species identification sheets for fishery purposes-Western Indian Ocean (Fishing Area-51) Vol. I-VI, Food and Agricultural Organization of the United Nations, Rome (1984).

Fowler, A.M. and D.J. Booth: How well do sunken vessels approximate fish assemblages on coral reefs? Conservation implications of vessel-reef deployments. Mar. Biol., 159, 2787-2796(2012).

Froese, R. and D. Pauly: FishBase: Cocepts, design and data sources, ICLARM, Laguna, Philippines (2015).

Gratwicke, B. and M.R. Speight: The relationship between fish species richness, abundance and habitat complexity in a range of shallow tropical marine habitats. J. Fish. Bio., 66, 650-667 (2005).

Gaur, A.S., Sundaresh, M. Saxena, S. Tripati and P. Gudigar: Preliminary observations on an $18^{\text {th }}$ century wreck at Poompuhar (east coast of India). Int. J. Nautical Archaeo., 26, 118-126 (1997).

Gudigar, P., S. Tripati, A.S. Gaur and Sundaresh: Some important shipwrecks on Konkan coast. J. Mar. Archaeo., 6, 45-48 (1996). 
Hughes, T.P., A.H. Baird, D.R. Bellwood, M. Card, S.R. Connolly, C. Folke, R. Grosberg, O. Hoegh-Guldberg, J.B. Jackson, J. Kleypas and J.M. Lough: Climate change, human impacts, and the resilience of coral reefs. Science, 301, 929-933(2003).

Lamb, J.B., J.D. True, S. Piromvaragorn and B.L. Willis: Scuba diving damage and intensity of tourist activities increased coral disease prevalence. Biol. Cons., 178, 88-96 (2014).

Lassau, S.A. and D.F. Hochuli: Effects of habitat complexity on ant assemblages. Ecography, 27, 157-164 (2004).

Manikandan, B., J. Ravindran, H. Mohan, R. Periasamy, R. Mani Murali and B.S. Ingole: Community structure and coral health status across the depth gradients of Grande Island, central west coast of India. Reg. Stud. Mar. Sci., 7, 150-158 (2016).

Manooch, C.S. and C.S. Barans: Distribution, abundance and age and growth of the tomate, Haemulon aurolineatum along the Southeastern United States Coast. Fishery Bull., 80, 1-19 (1982).

Murray, J.D. and C.J. Betz: User views of artificial reef management in the south-eastern U. S. Bull. Mar. Sci., 55, 970-981(1994).

Pitcher, T.J. and Jr.W. Seaman: Petrarch's Principle: How protected human-made reefs can help the reconstruction of fisheries and marine ecosystems. Fish Fish., 1, 73-81 (2000).

Rilov, G. and Y. Benayahu: Fish assemblage on natural versus artificial reefs; the rehabilitation perspective. Mar. Biol., 136, 931-942 (2000).

Rogers, A., J.L. Blanchard and P.J. Mumby: Vulnerability of coral reef fisheries to a loss of structural complexity. Curr. Biol., 24, 10001005 (2014).

Simon, T., J.C. Joyeux and H.T. Pinheiro: Fish assemblages on shipwrecks and natural rocky reefs strongly differ in trophic structure. Mar. Environ. Res., 90, 55-65(2013).

Sinopoli, M., P. Consoli, P. Perzia, T. Romeo and F. Andaloro: Distribution of fish fauna associated with a shipwreck in the Southern Tyrrhenian Sea: Vertical distribution and shipwreck structures. J. Appl. Ichthyol., 31, 96-101 (2015).

Stone, R.B.: National artificial reef plan. NOAA. Tech. Mem. NMFS OF6. Department of Commerce, National Marine Fisheries Service, Washington DC (1985)

Tripati, S. and P. Gudigar: Shipwreck archaeology of the Lakshadweep Islands, West coast of India. Int. J. Nautical Archaeo., 30, 37-47 (2001).

Tripati, S., A.S. Gaur and Sundaresh: Exploration of a steamship wreck off Amee shoals, Goa, India: A preliminary report. Int. J. Nautical Archaeo., 39, 182-189 (2010)

Venkataraman, K.: Handbook on Hard Corals of India. Zoological Survey of India, Kolkata, India (2003). 